\title{
Development of a Novel Polyclonal Antibody-Based Immunoassay for the Quantitation of Non-Albumin Urinary Proteins
}

\author{
Wallace B. Haigh $^{1}$, Donna M. Guralski ${ }^{1}$, Lisa M. Arrigo ${ }^{1}$, Jack T. Letsinger ${ }^{1}$, Michele Clarke ${ }^{2,3}$, \\ Richard J. MacIsaac ${ }^{2,4}$, George Jerums ${ }^{2,3}$, and Donald L. Very ${ }^{1, *}$ \\ ${ }^{1}$ The Institute for Bioanalytics, L.L.C., Branford, CT, 06456 USA \\ ${ }^{2}$ University of Melbourne, Melbourne, Victoria, Australia \\ ${ }^{3}$ Department of Endocrinology \& Diabetes, St. Vincent's Hospital, Melbourne, Victoria, Australia \\ ${ }^{4}$ Endocrine Centre, Austin Health, Melbourne, Victoria, Australia
}

\begin{abstract}
Background: Better diagnostic methods to detect urinary proteinuria or albuminuria, important indicators of diabetic kidney disease, are needed. Here, we describe the development and performance qualification of a new immunoassay for the quantitation of non-albumin urinary proteins of 20 to 90 kilodaltons.

Methods: Urinary proteins, purified from pooled, 24-hour, diabetic urines, were immunoabsorbed to remove albumin, electrophoretically characterized, and identified by mass spectrometry. Sheep anti-urinary protein polyclonal antibodies were immunoabsorbed to remove albumin reactivity. Major immunoreactive specificities of the polyclonal antibody were identified by Western blot. A polyclonal antibody-based competitive immunoassay was developed and performanceevaluated. An unpaired t-test $(\alpha=0.05)$ and a receiver-operating characteristic curve were used to evaluate the measurement of 24-hour urinary protein excretion rates in distinguishing between normal, proteinuric, and albuminuric samples.
\end{abstract}

Results: Approximately $380 \mathrm{mg}$ of urinary protein was purified from $6.0 \mathrm{~g}$ of total urinary proteins. Mass spectrometry identified more than 36 different proteins in the purified preparation. The anti-urinary protein polyclonal antibody possessed significant immunoreactivity towards transferrin, IgG chains, alpha-1-acid glycoprotein, zinc-alpha-2-glycoprotein, prostaglandin-H2-d-isomerase, and alpha-1-microglobulin. The competitive immunoassay exhibited excellent analytical and clinical performance. Measurement of urinary protein excretion rates could distinguish between normoproteinuric and proteinuric samples $(\mathrm{p}<0.0001$; area under the curve $=0.6900)$ and between normoalbuminuric and albuminuric samples $(\mathrm{p}<0.0001$; area under the curve $=0.8782)$.

Conclusion: Measurement of urinary protein excretion rates using the urinary protein immunoassay is clinically equivalent to laboratory methods of quantitating total urinary protein or albumin in identifying proteinuria and albuminuria.

Keywords: Albuminuria, glomerular filtration, immunoassay, proteinuria, tubular reabsorption.

\section{INTRODUCTION}

Diabetes is the principal cause of end stage renal disease (ESRD) and kidney failure [1,2]. Worldwide, among patients initiating treatment for ESRD, $14 \%$ to $60 \%$ are diabetic [3]. In the United States in 2010, there were 50536 new cases of diabetes-related ESRD, accounting for $54.3 \%$ of all new cases [3]. As the incidence and prevalence of diabetes increases to an estimated 380 million people worldwide by the year 2025 [4], the number of patients with diabetic kidney disease will increase, with a resulting increase in morbidity and mortality.

\footnotetext{
*Address correspondence to this author at the PharmLogic, LLC; 85 Tollgate Road; Warwick, RI, 02886 USA; Tel: 908-489-2850;

Fax: 401-732-8512; E-mail: donaldvery@hotmail.com
}

Urinary proteinuria is an important clinical indicator of diabetic glomerular kidney disease and disease progression. The protein content of urine is the result of the physiological processes of glomerular filtration and tubular reabsorption. In normal individuals, moderate molecular weight proteins, like albumin, that are not retained by the glomerulus are reabsorbed in the proximal tubules, resulting in a total protein excretion of less than $150 \mathrm{mg}$ per day [5]. As glomerular disease progresses, the excretion of both total urinary proteins and specific proteins, such as albumin, increases and becomes diagnostically significant [6]. Numerous studies have shown that early therapeutic intervention in type II diabetic patients can decrease the level of urinary proteinuria and albuminuria and can delay the onset of ESRD [7-9].

Many quantitative assays exist to measure urinary proteinuria and albuminuria. Methods to quantitate total urinary proteins employ dye-binding $[10,11]$, turbidity following 
protein precipitation [12], precipitation using trichloroacetic acid [13], and biuret reagent [14]. Albumin can be quantitated by antibody-based methods such as nephelometry, immunoturbidimetry, radioimmunoassay, and enzyme immunoassay $[15,16]$. While these methods have advantages, all have significant disadvantages that can adversely affect their clinical utility. Dye-binding assays quantitate proteins differently due to differential binding to various proteins making standardization of results difficult $[17,18]$. Additionally, the measurement of urinary proteins at low concentrations of total protein is not accurate or precise [18-20]. The accurate and precise quantitation of urinary albumin using immunoassays can be limited by the epitopic specificity of the antibodies used in the assays, and the lack of a suitable reference standard and reference procedure $[18,21]$. Also, as albumin is a moderately large protein of approximately 68 kilodaltons $(\mathrm{kDa})$, a significant amount of glomerular and/or tubular impairment must have already occurred in order for a pathological amount of albumin and other large molecular weight proteins to be detected in the urine [5]. Clearly, improved methods of detecting urinary proteinuria are needed so that that renoprotective therapy can be initiated, thereby reducing disease-associated morbidity and mortality.

Here, we describe the development and performance evaluation of a novel competitive immunoassay for the quantitation of non-albumin urinary proteins. The key components of this immunoassay are: a purified and biochemically characterized collection of $20 \mathrm{kDa}$ to $90 \mathrm{kDa}$, non-albumin, urinary proteins that were purified from 24-hour collections of urine from non-diabetic and diabetic patients; and an immunologically characterized polyclonal antibody specific for the purified urinary proteins. Additionally, we demonstrate the clinical equivalence of this new test to clinical laboratory methods of detecting proteinuria and albuminuria by the analysis of 24-hour urine samples obtained from a collection of 343 normoproteinuric and proteinuric diabetic patients.

\section{MATERIALS AND METHODOLOGY}

\section{Human Urine Samples}

For the purification of urinary proteins, twenty-four hour collections of human urine from normoproteinuric (protein excretion $<150 \mathrm{mg}$ per 24 hours; $\mathrm{n}=5$ ) and proteinuric diabetics (protein excretion $\geq 150 \mathrm{mg}$ per 24 hours; $\mathrm{n}=7$ ) were obtained from AusAM Diagnostics, Inc. (Melbourne, Victoria, Australia). Urine from all donors was pooled (approximately $22.5 \mathrm{~L}$, total volume) prior to urinary protein purification. Single timepoint collections of individual urine samples and sample pools (three to five donors), used to performance qualify the urinary protein immunoassay, were obtained from Bioreclamation, Inc. (Westbury, NY, USA). Twenty-four hour urine collections from 343 diabetic donors (normoproteinuric, $\mathrm{n}=291$; proteinuric $\mathrm{n}=52$; normoalbuminuric, albumin excretion $<30 \mathrm{mg}$ per 24 hours, $\mathrm{n}=281$; albuminuric, albumin excretion $\geq 30 \mathrm{mg}$ per 24 hours, $\mathrm{n}=$ 62 ), used to evaluate the clinical equivalency of the antiurinary protein immunoassay, were obtained from the Endocrine Centre, Austin Health (Melbourne, Victoria, Australia). Total urinary protein concentration in 24-hour samples was determined using the Microprotein (M-TP) method, a timed endpoint, pyrogallol red - molybdate binding assay, on
Beckman Coulter's SYNCHRON System (Brea, CA, USA). Albumin concentrations were determined using the Microalbumin (MA) method, an immunoturbidimetric method, on the SYNCHRON System. All urine samples were adjusted to pH 9.0 and stored at $-20^{\circ} \mathrm{C}$ prior to analysis.

All human urine samples used in these retrospective studies were collected under informed donor consent in accordance with the policies and procedures of the Institutional Review Board of the organization that provided the samples.

\section{Purification of Urinary Proteins from Human Urine}

Urinary proteins were purified from pooled, twenty-four hour urines collected from twelve diabetic patients as summarized in Fig. (1). Pooled human urine was thawed, $1 \mathrm{mM}$ EDTA and $150 \mu \mathrm{M}$ PMSF were added, and urine was centrifuged at $10000 \mathrm{x} \mathrm{g}, 4^{\circ} \mathrm{C}, 45$ minutes. The supernatant was salt fractionated with $85 \%\left(\mathrm{NH}_{4}\right)_{2} \mathrm{SO}_{4}$ overnight at $4^{\circ} \mathrm{C}$. Following centrifugation $\left(10000 \mathrm{x} \mathrm{g}, 4^{\circ} \mathrm{C}, 45\right.$ minutes), the pellet was resuspended and dialyzed overnight at $4^{\circ} \mathrm{C}$ versus 50 $\mathrm{mM}$ Tris, $\mathrm{pH} 8.0$ and $250 \mathrm{mM} \mathrm{NaCl}, \mathrm{pH} 7.4$. Aliquots of the precipitated protein preparations were passed over an antihuman serum albumin antibody (Dako Cytomation, Glostrup, Denmark) immunoaffinity column to remove albumin from the preparation. Column flow-through fractions were collected, pooled, and concentrated using a Centriprep ${ }^{\mathrm{TM}}$ YM-30 device (EMD Millipore, Billerica, MA, USA). The retentate from the filtration was further purified by high performance liquid chromatography (HPLC) using two Sephadex GF-250 gel filtration columns. Column fractions were characterized by sodium dodecyl sulfate-polyacrylamide gel electrophoresis (SDS-PAGE) and aliquots corresponding to urinary proteins of molecular weight 20 to 90 $\mathrm{kDa}$ were pooled to yield the final preparation of urinary proteins.

During urinary protein purification, all protein concentrations were determined using a Pierce BCA Protein Determination Kit (Thermo Scientific, Rockford, IL, USA).

\section{Polyacrylamide Gel Electrophoresis and Western Blot Analysis of Urinary Proteins}

Purified urinary protein preparations were characterized by the SDS-PAGE method of Fairbanks [22] and by the nondenaturing PAGE method of Ornstein [23] using precast, Novex, $12 \%$ acrylamide gels (Life Technologies Corporation, Carlsbad, CA, USA) at $20 \mathrm{~mA}$ per gel for 8 hours at $4^{\circ} \mathrm{C}$. Molecular weight standards (Bio-Rad Laboratories, Hercules, CA), purified protein standards (Sigma-Aldrich), and protein bands were visualized by staining with $1 \%$ Coomassie Blue R250 in 50\% methanol, 10\% acetic acid.

For Western blot analysis, protein bands were blotted onto polyvinylidene fluoride (PVDF) membranes (EMD Millipore) in transfer buffer $(50 \%$ methanol, $10 \%$ acetic acid) at $200 \mathrm{~V}$ for 6 hours at $4^{\circ} \mathrm{C}$. Membranes containing transferred proteins were blocked with $1 \%$ casein (SigmaAldrich) in PBS and sequentially incubated for 1 hour at room temperature in $10 \mu \mathrm{g} / \mathrm{mL}$ of anti-urinary protein polyclonal antibody followed by $2 \mu \mathrm{g} / \mathrm{mL}$ of goat anti-sheep IgGhorseradish peroxidase (Sigma-Aldrich). Immunoreactive protein bands were visualized by the sequential addition of 


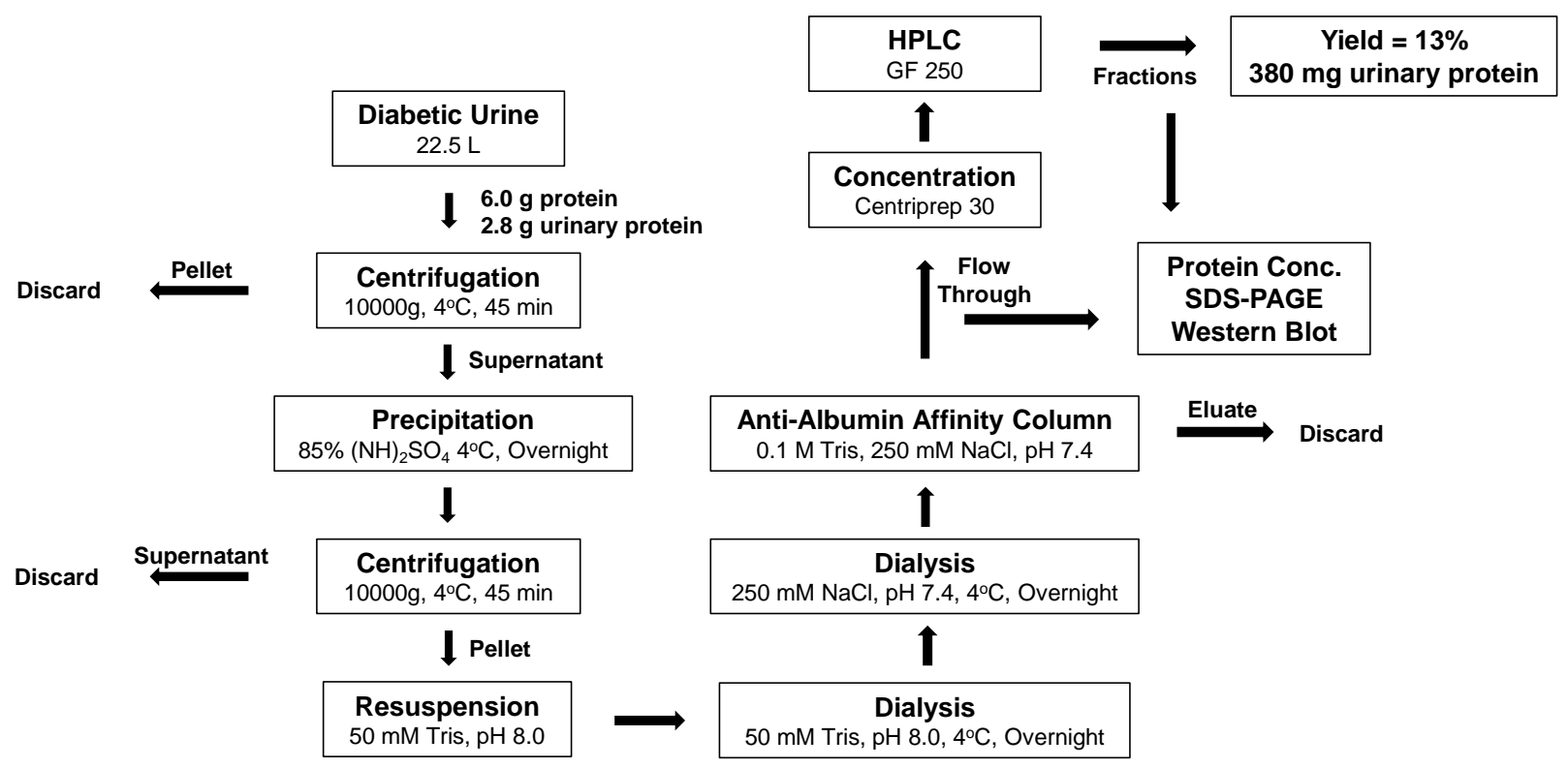

Fig. (1). The biochemical purification strategy used to purify urinary proteins from human diabetic urine. Urinary proteins, from pooled human diabetic urine, were purified by a sequential series of centrifugation, salt fractionation, affinity chromatography, and HPLC gel filtration procedures as described in Materials and Methodology. Approximately $380 \mathrm{mg}$ of purified urinary protein was obtained from approximately $2.8 \mathrm{~g}$ of total urinary protein.

TMB Substrate Solution (Thermo Scientific) and a $0.1 \mathrm{~N}$ $\mathrm{NaOH}$ stop solution.

\section{LC-MS/MS Analysis of Urinary Protein Preparations}

To promote the detection of less abundant proteins in the urinary protein preparation by liquid chromatographytandem mass spectrometry (LC-MS/MS) analysis, transferrin (Trf) and $\operatorname{IgG}$ were removed from the albumin-absorbed, urinary protein preparation by sequential immunoaffinity absorption using an anti-Trf monoclonal antibody (SigmaAldrich Corporation, St. Louis, MO, USA) and a goat antihuman IgG antibody (Bethyl Laboratories, Inc., Montgomery, TX, USA). Absorptions were performed using the Pierce Hybridization Buffer System (Thermo Scientific).

Urinary protein bands in slices of non-denaturing gels were excised and eluted in $100 \mu \mathrm{L}$ of $0.1 \mathrm{M}$ TBS $\mathrm{pH} 8.4$ overnight at $4^{\circ} \mathrm{C}$ and dialyzed versus $0.1 \mathrm{M}$ TBS pH 8.4 containing $\mathrm{NaCl}$ and magnesium [24]. Proteins eluted from the gel slices and aliquots of the albumin-Trf-IgG-absorbed urinary protein preparation were digested with trypsin and endoproteinase Lys-C (Lys-C) for 1 hour at $37^{\circ} \mathrm{C}$, and lyophilized. Digestions of proteins eluted from gel slices [24] and from aliquots of the albumin-Trf-IgG-absorbed urinary protein preparation [25] were performed as previously described. LC-MS/MS analysis of digested urinary protein and gel slice preparations of urinary proteins was performed by Transitions Therapeutics, Inc. (Toronto, Ontario, Canada) and the Keck Biotechnology Resource Laboratory at Yale University (New Haven, CT, USA), respectively. For each protein detected, each site generated an "Average Abundance Score" (a measure of the relative confidence of specific protein detection) and reported the "Average Number of Peptides Detected." The abundance score and number of peptides detected for each specific protein is reported as the average of the duplicate determinations from both testing sites.

\section{Production and Purification of the Anti-urinary Protein Polyclonal Antibodies}

The production and purification of sheep polyclonal antibodies to the albumin-absorbed urinary protein preparation is summarized in Fig. (2). Six outbreed sheep were sequentially immunized with $0.5 \mathrm{mg}$ of purified, albumin-absorbed, urinary protein by Rockland Immunochemicals, Inc. (Gilbertsville, PA, USA) according to their 60 day protocol. Production bleeds on all animals were performed on day 58 and every 60 days thereafter. All prebleed, testbleed, and production bleed anti-urinary protein antibody titers were determined by direct-binding ELISA. Additionally, all prebleed, testbleed, and production bleeds were evaluated for antiurinary protein reactivity by Western blot.

Crude sheep anti-urinary protein antiserum was diluted 1:2 in PBS, $250 \mathrm{mM} \mathrm{NaCl}, \mathrm{pH} 7.4$ and batch purified by sequential immunoaffinity chromatography using a $5 \mathrm{~mL}$ Protein G Plus column (Thermo Scientific) to concentrate serum IgG, a $100 \mathrm{~mL}$ human serum albumin column containing $5 \mathrm{~g}$ of albumin to remove human serum albumin-specific antibodies, and a $10 \mathrm{~mL}$ urinary protein column containing $50 \mathrm{mg}$ of urinary protein to purify anti-urinary protein antibodies. One $\mathrm{mL}$ fractions of anti-urinary protein-specific antibodies were eluded from the urinary protein column using $0.1 \mathrm{M}$ acetic acid. Column fractions were neutralized and monitored for protein content by absorbance at $280 \mathrm{~nm}$. Fractions with the highest absorbance were pooled and dialyzed overnight at $4^{\circ} \mathrm{C}$ versus $\mathrm{PBS}$. 


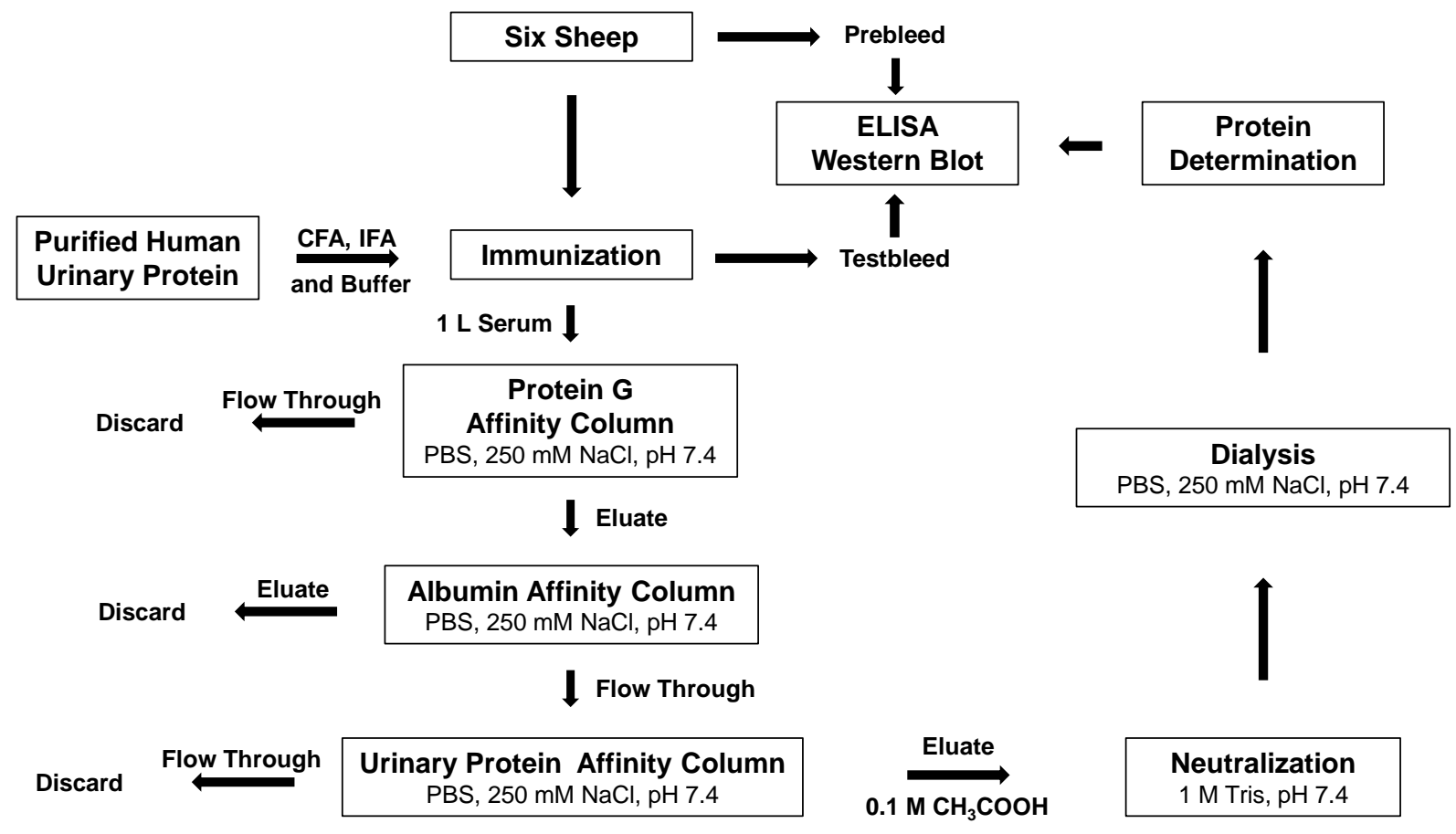

Fig. (2). Production and biochemical purification of the sheep anti-urinary protein polyclonal antibody. Six outbred sheep were sequentially immunized with purified human urinary protein emulsified in Complete Freund's Adjuvant (CFA), Incomplete Freund's Adjuvant (IFA) or phosphate buffered saline. Sheep anti-UP polyclonal antibodies were purified from high titered antisera by sequential affinity chromatography using Sephadex columns covalently conjugated with protein $G$, human serum albumin, and purified urinary protein as described in Materials and Methodology.

\section{The Urinary Protein Competitive ELISA}

A competitive ELISA, employing the purified urinary protein preparation and the purified sheep polyclonal antiurinary protein antibody preparation, was developed for use in clinical sample analysis. In this assay, the purified urinary protein preparation, that was absorbed to remove only albumin, was used to coat the microtiter plate and as an assay standard. Urinary protein, coated onto the microtiter plate or present in a clinical sample or assay standard, competed for the binding of biotinylated sheep anti-urinary protein polyclonal antibodies. For use in the ELISA, the sheep antiurinary protein antibodies were biotinylated using an E-Z Link Sulfo-NHS Biotinylation Kit (Thermo Scientific).

Immulon 4HBX 96-well microtiter plates (Thermo Scientific) were coated with $100 \mu \mathrm{L}$ per well of $0.5 \mu \mathrm{g} / \mathrm{mL}$ of albumin-absorbed urinary protein for 1 hour at room temperature. Following aspiration, the plate was blocked with $150 \mu \mathrm{L}$ per well of $0.5 \mathrm{mg} / \mathrm{mL}$ ovalbumin (Sigma-Aldrich) in PBS, $0.05 \%$ Tween-20 for 1 hour at room temperature, and washed four times with $300 \mathrm{uL}$ per well of PBS, $0.05 \%$ Tween-20. To each well of the plate: $50 \mu \mathrm{L}$ per well of PBS, $0.05 \%$ Tween-20; $25 \mu \mathrm{L}$ per well of serially-diluted, albumin-absorbed urinary proteins (assay standards that are serial dilutions of the urinary protein preparation used for sheep immunization; $4 X$ concentration, $100 \mu \mathrm{g} / \mathrm{mL}$ to $0.39 \mu \mathrm{g} / \mathrm{mL}$; final concentration, $20 \mu \mathrm{g} / \mathrm{mL}$ to $0.10 \mu \mathrm{g} / \mathrm{mL}$ ) or sample dilution; and $25 \mu \mathrm{L}$ per well of biotinylated anti-urinary protein polyclonal antibody (4X concentration, $820 \mathrm{ng} / \mathrm{mL}$; final concentration, $205 \mathrm{ng} / \mathrm{mL}$ ) was added and incubated for 1 hour at room temperature. Following washing, color was developed by sequential addition of $100 \mu \mathrm{L}$ per well of a 1:25000 dilution of streptavidin-horseradish peroxidase (Sigma-Aldrich) in PBS, $0.05 \%$ Tween-20 for 1 hour at room temperature; $100 \mu \mathrm{L}$ per well of TMB substrate (Sigma-Aldrich) for 20 minutes at room temperature in the dark; and $75 \mu \mathrm{L}$ per well of $1 \mathrm{M} \mathrm{H}_{2} \mathrm{SO}_{4}$. The concentration of urinary protein in samples was determined using a fourparameter standard curve fit of optical density at $450 \mathrm{~nm}$ versus urinary protein concentration of assay standards. Sample analysis results were reported as the mean of duplicate determinations.

\section{Performance Evaluation of the Urinary Protein Competi- tive ELISA}

The analytical performance of the urinary protein competitive ELISA was evaluated by determining the assay's interassay precision, dynamic range, upper limit of quantitation (ULQ), lower limit of quantitation (LLQ), accuracy, and dilution linearity. The interassay precision of assay standards and three pools of human urine (high, medium, and low concentrations of urinary proteins) was determined in 12 separate interassay precision runs. The average urinary protein concentration and percent coefficient of variation $(\% \mathrm{CV})$ were determined across all 12 interassay precision runs. The ULQ and LLQ of the assay were defined as the highest and lowest calibrator concentrations giving acceptable precision $(\% \mathrm{CV} \leq 20 \%)$ in the interassay precision evaluation. The dynamic range of the assay was defined as the LLQ - ULQ. To evaluate assay accuracy, aliquots of three urine samples 
were spiked with three concentrations of urinary protein $(10$, 50 , and $150 \mu \mathrm{g} / \mathrm{mL}$ ). As controls, 10,50 , and $150 \mu \mathrm{g} / \mathrm{mL}$ concentrations of urinary protein were also spiked into PBS. Spiked urine and PBS samples, and unspiked aliquots of each urine sample, were analyzed in the immunoassay. The $\%$ recovery of urinary protein in each spiked sample was determined as:

$\%$ recovery $=$ (observed urinary protein concentration/ expected urinary protein concentration) x 100

The observed concentration equals the urinary protein concentration in each spiked sample (as determined by the immunoassay), and the expected concentration equals the urinary protein concentration of the spiked PBS control plus the urinary protein concentration of the unspiked sample. The average \% recovery for each sample across all three spiked concentrations was determined. The dilution linearity of the assay was evaluated by determining the \% recovery of endogenous urinary protein in a sample of pooled of human urine that was diluted from 1:5 to 1:200. All calculations of average urinary protein concentrations, $\% \mathrm{CV}$, and $\%$ recovery were determined using EXCEL software (Microsoft, Redmond, WA, USA). In all performance qualification analyses, samples whose concentrations fell outside the analytical range of the assay were diluted and reanalyzed until the determined concentration fell within the analytical range of the assay. The urinary protein concentration determined upon sample dilution was then multiplied by the sample dilution factor to determine the urinary protein concentration in the undiluted sample.

The clinical equivalence of the urinary protein assay results to total protein assay results, determined using Beckman Coulter's SYNCHRON M-TP method, or to albumin assay results, determined using Beckman Coulter's SYNCHRON MA method was evaluated by the analysis of 24 hour urine samples collected from 343 diabetic samples. All samples were analyzed in duplicate in each of the three assay with the mean $(\mathrm{m})$ of the individual replicates reported as the sample analysis result. Samples were classified as normoproteinuric $(n=291)$ or proteinuric $(n=52)$ based on 24 hour total protein excretion results using the M-TP method, or as normoalbuminuric $(\mathrm{n}=281)$ or albuminuric $(\mathrm{n}=62)$ based on 24 hour excretion results using the MA method. Clinical equivalence of 24 hour urinary protein excretion rates (UPER, units of mg per 24 hours), determined using the urinary protein assay, in identifying proteinuria or albuminuria was assessed by statistical comparison of UPER results in normoproteinuric and proteinuric samples, and in normoalbuminuric and albuminuric samples using a two-tailed, unpaired t-test $(\alpha=0.05)$. In these statistical comparisons, as the sample sizes are large, standard error of the mean (SEM) was used, instead of standard deviation, as an expression of sample variance. Additionally, a receiver-operating characteristic (ROC) curve of UPER cutoff values was generated to assess the ability of a UPER measurement to identify proteinuric or albuminuric samples. Graphical representation of UPER sample analysis results, the ROC curves, and calculation of the sample replicate $\mathrm{m}$, SEM, $\mathrm{t}$ statistics, $\mathrm{p}$ values, area under the curves (AUC), and the $95 \%$ confidence inter- val (CI) of the AUC were performed using GraphPad PRISM 5.00 software (GraphPad Software, Inc., San Diego, CA, USA).

\section{RESULTS}

\section{Purification of Proteins from Human Diabetic Urine}

Urinary proteins were purified from pooled, twenty-four hour urines collected from twelve diabetic patients as described. Following removal of endogenous albumin via immunoaffinity chromatography, the urinary protein preparation was passed over a size-exclusion column and the flowthrough fractions (Fig. 3, panel A) were analyzed by reducing SDS-PAGE (Fig. 3, panel B). Electrophoretic analysis revealed that all column fractions contained a heterogeneous

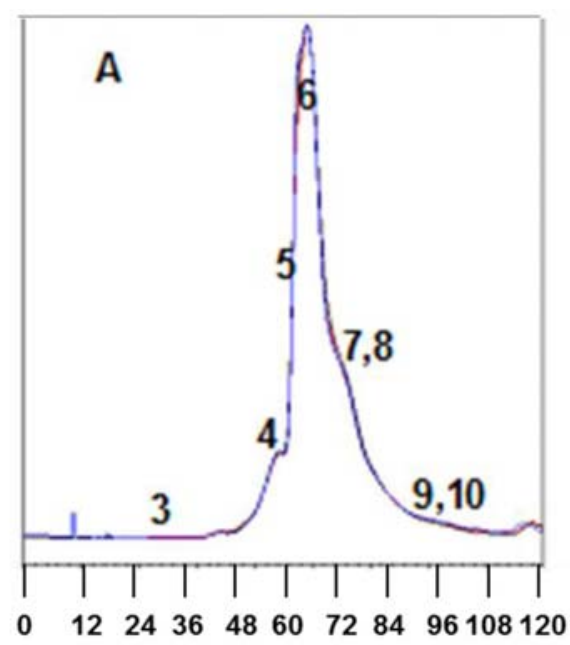

\section{Time (minutes)}



Fig (3). Gel filtration and reducing SDS-PAGE analysis of purified urinary proteins revealed a complex mixture of proteins that did not contain albumin. During purification, urinary protein preparations were subjected to HPLC size exclusion chromatography using a GF-250 column (panel A). Column flow-through fractions were collected (numbered in panel A) and further analyzed by reducing SDS-PAGE (panel B). SDS-PAGE lanes 1 and 12, molecular weight standards with molecular weights indicated in units of kilodaltons; lane 2, partially purified, albumin depleted, urinary protein preparation that was loaded onto HPLC column; lanes $3-10$, HPLC column fractions 3 to 10 from panel A; and lane 11, commercially obtained, purified, human serum albumin standard. 
collection of proteins of varying molecular weights and that the immunoaffinity procedure was successful in removing all detectable albumin from the urinary protein preparation. HPLC column fractions 4 through 8 (corresponding to urinary proteins of approximately 20 to $90 \mathrm{kDa}$ ) were pooled to constitute the final urinary protein preparation. From approximately $22.5 \mathrm{~L}$ of pooled urine, containing $6 \mathrm{~g}$ of total protein and $2.8 \mathrm{~g}$ of urinary protein (as determined by the urinary protein immunoassay), $380 \mathrm{mg}$ of purified urinary protein was obtained, corresponded to a yield of $13.6 \%$.

\section{Identification of Proteins in the Urinary Protein Prepara- tion}

To identify the specific proteins present in the urinary protein preparation, aliquots of the urinary protein preparation that were initially absorbed to remove albumin, were further absorbed to remove Trf, and IgG. These additional absorptions were performed to facilitate the LC-MS/MS detection of proteins and peptides in the preparation that were present in smaller amounts than Trf and IgG. The albuminTrf-IgG absorbed urinary protein preparation and an aliquot of the urinary protein preparation that was absorbed to remove albumin only, were analyzed by non-denaturing Western blot and stained with Coomassie Blue (Fig. 4). Both the stained gel and the PVDF membrane demonstrated successful removal of detectable albumin from the albumin onlyabsorbed aliquot, and successful removal of albumin, Trf, and IgG from the albumin-Trf-IgG-absorbed preparation. The major protein bands in the albumin-Trf-IgG-absorbed preparation (identified in Fig. (4), lane 6 by horizontal rec- tangles), and an aliquot of the albumin only-absorbed urinary protein preparation were protease digested and analyzed by LC-MS/MS. The results of the LC-MS/MS analysis of the urinary protein preparation (Table 1) demonstrate that the preparation consists of a very heterogeneous collection of proteins and peptides of varying molecular weight.

\section{Production and Biochemical Characterization of the Sheep Polyclonal Anti-urinary Protein Antibody}

Six outbred sheep were sequentially immunized with albumin-absorbed urinary protein and anti-urinary protein polyclonal antibodies were purified as described in Materials and Methodology. By direct-binding ELISA, all animals produced high-titered anti-urinary protein antisera with immunization (data not presented). Analysis of the immunoreactivity of purified anti-urinary protein polyclonal antibodies by non-denaturing Western Blot demonstrated significant immunoreactivity with a majority of the protein components of the preparation (Fig. 5). Use of purified or recombinant proteins and specific antibodies in Western blot analyses identified Trf, IgG heavy chain, IgG kappa chain, alpha-1 acid glycoprotein, zinc alpha-2 glycoprotein, prostaglandinH2-D-isomerase, and alpha-1 microglobulin as the major immunoreactive specificities of the anti-urinary protein polyclonal antibodies (Fig. 5).

\section{Performance Evaluation of the Competitive Urinary Pro- tein ELISA}

The results of the analytical performance evaluation of the urinary protein ELISA are presented in Tables 2 and 3.

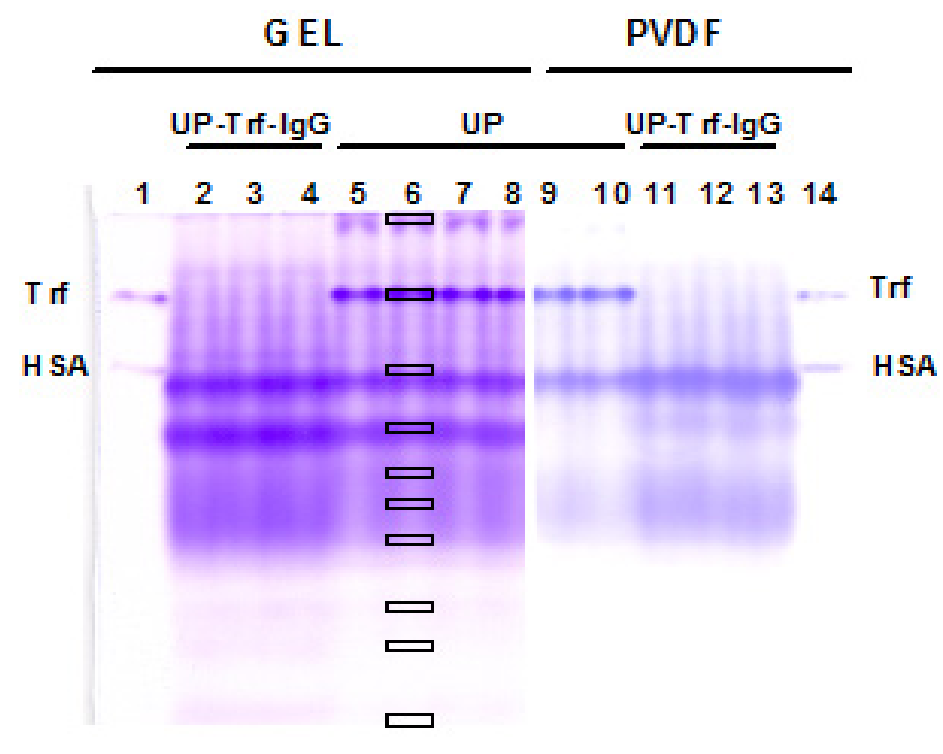

Fig. (4). Non-denaturing polyacrylamide gel electrophoresis and Western blot analysis of urinary protein preparations. Albumin-depleted urinary protein (UP) preparations that were further immunoaffinity absorbed to remove endogenous transferrin (Trf) and IgG (UP-Trf-IgG; lanes 2-4 and 11-13) and albumin-depleted urinary protein preparations that were not absorbed to remove Trf and IgG (UP, lanes 5-10) were subjected to non-denaturing polyacrylamide gel electrophoresis (GEL), Western blotted onto a polyvinylidene difluoride (PVDF) membrane, and stained with Commassie Blue to reveal the protein content. Trf and human serum albumin (HSA) standards were commercially obtained and analyzed in lanes 1 and 14 as indicated. Gel bands in lane 6, as indicated by the horizontal rectangles, were excised from the gel. The proteins in the excised bands were eluted, digested with trypsin and Lys-C, and analyzed by LC-MS/MS to identify urinary proteins present. 
Table 1. Relative Abundance of Proteins Present in Urinary Protein Preparations as Determined in Duplicate LC-MS/MS Experiments

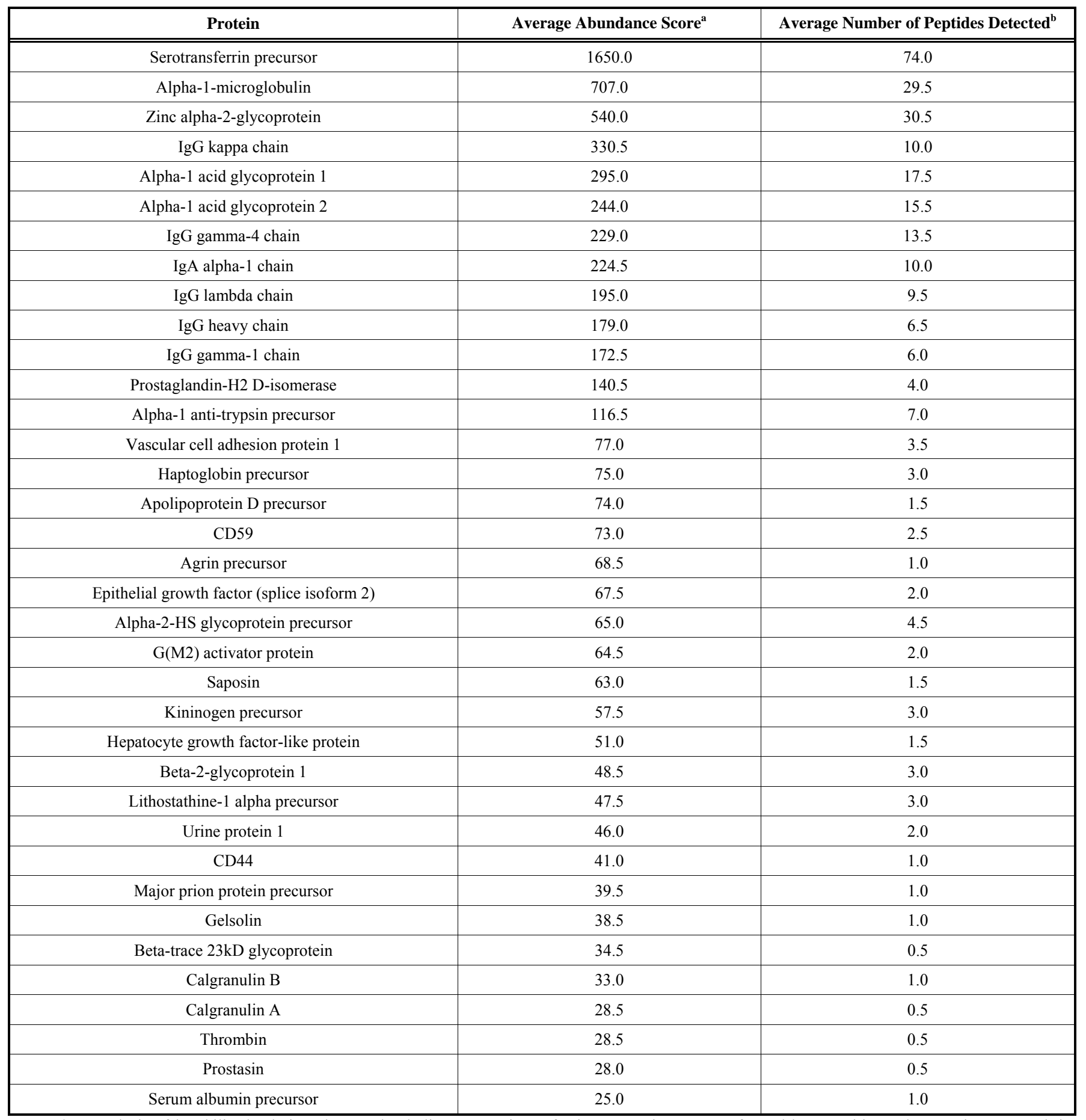

LC-MS/MS analysis of lyophilized solution phase and gel slice preparations of urinary proteins were performed by Transitions Therapeutics, Inc. and the Keck Biotechnology Resource Laboratory at Yale University, respectively.

${ }^{a}$ Measure of the relative confidence of protein detection. Reported score is the average of duplicate LC-MS/MS analyses of the same urinary protein preparation at both testing sites.

${ }^{\mathrm{b}}$ Calculated as the average number of proteins detected in duplicate LC-MS/MS analyses of the same urinary protein preparation at both testing sites.

The average interassay precision of assay calibrators and three pools of human urine ranged from $6.9 \% \mathrm{CV}$ to 20.6 $\% \mathrm{CV}$ across twelve separate precision runs. The average $\%$ recovery (accuracy) of spiked urinary protein in all three urine samples ranged from $104.2 \%$ to $108.3 \%$ (Table 2 ). In the dilution linearity assessment, recovery of urinary protein at all dilutions tested ranged from $96.3 \%$ to $102.9 \%$. The dynamic range of the urinary protein assay was determined to be $0.08 \mu \mathrm{g} / \mathrm{mL}$ to $20 \mu \mathrm{g} / \mathrm{mL}$ (Table 3 ). 
Table 2. Performance Evaluation of the Urinary Protein Competitive ELISA: Interassay Precision and Spike Recovery

\begin{tabular}{|c|c|c|}
\hline \multirow{2}{*}{ Interassay Precision $^{\mathrm{a}}$} & Average UP Concentration & \multirow{2}{*}{$\% \mathrm{CV}$} \\
\hline & $(\mu \mathrm{g} / \mathrm{mL})$ & \\
\hline Standard $0.10 \mathrm{ug} / \mathrm{mL}$ & 0.09 & 14.7 \\
\hline Standard $0.25 \mathrm{ug} / \mathrm{mL}$ & 0.25 & 10.9 \\
\hline Standard $0.74 \mathrm{ug} / \mathrm{mL}$ & 0.74 & 9.1 \\
\hline Standard $2.20 \mathrm{ug} / \mathrm{mL}$ & 2.25 & 6.9 \\
\hline Standard $6.60 \mathrm{ug} / \mathrm{mL}$ & 6.19 & 9.5 \\
\hline Standard $20.00 \mathrm{ug} / \mathrm{mL}$ & 21.91 & 10.2 \\
\hline Human urine pool 1 (low) & 3.40 & 18.9 \\
\hline Human urine pool 2 (med) & 20.00 & 20.6 \\
\hline Human urine pool 3 (high) & 66.60 & 20.0 \\
\hline Spike Recovery ${ }^{b}$ & \% Recovery & Average \% Recovery \\
\hline Urine sample $1,10 \mathrm{ug} / \mathrm{mL}$ & 103.1 & \multirow{3}{*}{108.3} \\
\hline Urine sample $1,50 \mathrm{ug} / \mathrm{mL}$ & 102.3 & \\
\hline Urine sample $1,150 \mathrm{ug} / \mathrm{mL}$ & 119.4 & \\
\hline Urine sample 2, $10 \mathrm{ug} / \mathrm{mL}$ & 97.2 & \multirow{3}{*}{104.2} \\
\hline Urine sample $2,50 \mathrm{ug} / \mathrm{mL}$ & 120.6 & \\
\hline Urine sample $2,150 \mathrm{ug} / \mathrm{mL}$ & 94.7 & \\
\hline Urine sample 3, $10 \mathrm{ug} / \mathrm{mL}$ & 108.3 & \multirow{3}{*}{106.7} \\
\hline Urine sample $3,50 \mathrm{ug} / \mathrm{mL}$ & 94.2 & \\
\hline Urine sample $3,150 \mathrm{ug} / \mathrm{mL}$ & 117.5 & \\
\hline
\end{tabular}

${ }^{a}$ Interassay precision of each calibrator level and three human urine pools was determined from twelve individual interassay precision runs. The average urinary protein concentration and $\% \mathrm{CV}$ was calculated across all twelve runs.

${ }^{b}$ Aliquots of three human urine samples were spiked with three different concentrations of urinary protein assay standard. The average \% recovery reported for each sample is the average recovery for that sample across all three spiked concentrations.

Clinical Equivalence of the Urinary Protein ELISA Results to the Results Obtained Using Established Laboratory Methods of Quantitating Urinary Total Protein or Albumin

The clinical equivalence of 24 hour UPER, determined by the urinary protein immunoassay, to 24 hour total protein excretion rates or 24 albumin excretion rates, determined using established clinical laboratory methods, was evaluated using an unpaired t-test and generation of a ROC curve. Measurement of 24 hour UPER by the urinary protein immunoassay was able to distinguish between normoproteinuric $(\mathrm{n}=291 ; \mathrm{m} \pm \mathrm{SEM}=50.8 \pm 2.3 \mathrm{mg}$ UPER per 24 hours $)$ and proteinuric $(\mathrm{n}=52 ; \mathrm{m} \pm \mathrm{SEM}=74.3 \pm 6.4 \mathrm{mg}$ UPER per 24 hours ) patient samples with statistical significance (p $<0.0001, \alpha=0.05$ ), while a ROC curve of 24 hour UPER results in this sample collection had an AUC of $0.6900(95 \%$ $\mathrm{CI}=0.6108$ to 0.7692 , Fig. 6). Measurement of 24 hour UPER by immunoassay was also able to distinguish between normoalbuminuric $(\mathrm{n}=281 ; \mathrm{m} \pm \mathrm{SEM}=43.1 \pm 1.6 \mathrm{mg}$ UPER per 24 hours $)$ and albuminuric $(\mathrm{n}=62 ; \mathrm{m} \pm$ SEM $=$ $105.2+6.6 \mathrm{mg}$ UPER per 24 hours) patient samples with similar statistical significance $(\mathrm{p}<0.0001, \alpha=0.05)$, while a ROC curve of UPER results in normoalbuminuric and albu-
Table 3. Performance Evaluation of the Urinary Protein Competitive ELISA: Dilution Linearity and Dynamic Range

\begin{tabular}{|c|c|}
\hline Dilution linearity $^{\text {a }}$ & \% Recovery $^{\text {(1) }}$ \\
\hline \hline Urine pool, 1:5 dilution & 102.6 \\
\hline Urine pool, 1:10 dilution & 99.9 \\
\hline Urine pool, 1:25 dilution & 96.3 \\
\hline Urine pool, 1:50 dilution & 98.1 \\
\hline Urine pool, 1:75 dilution & 90.4 \\
\hline Urine pool, 1:100 dilution & 102.5 \\
\hline Urine pool, 1:200 dilution & 97.6 \\
\hline Dynamic Range & Value \\
\hline \hline ULQ & $20 \mathrm{ug} / \mathrm{mL}$ \\
\hline LLQ & $0.08 \mathrm{ug} / \mathrm{mL}$ \\
\hline Range of the assay & $0.08-20 \mathrm{ug} / \mathrm{mL}$ \\
\hline
\end{tabular}

${ }^{a}$ Percent recovery of urinary protein was determined at each dilution of a pool of human urine.

${ }^{b}$ Range of the assay is presented as the assay's LLQ - ULQ. LLQ and ULQ were defined as the lowest and highest assay calibrators with interassay precision $\leq 20 \%$. 


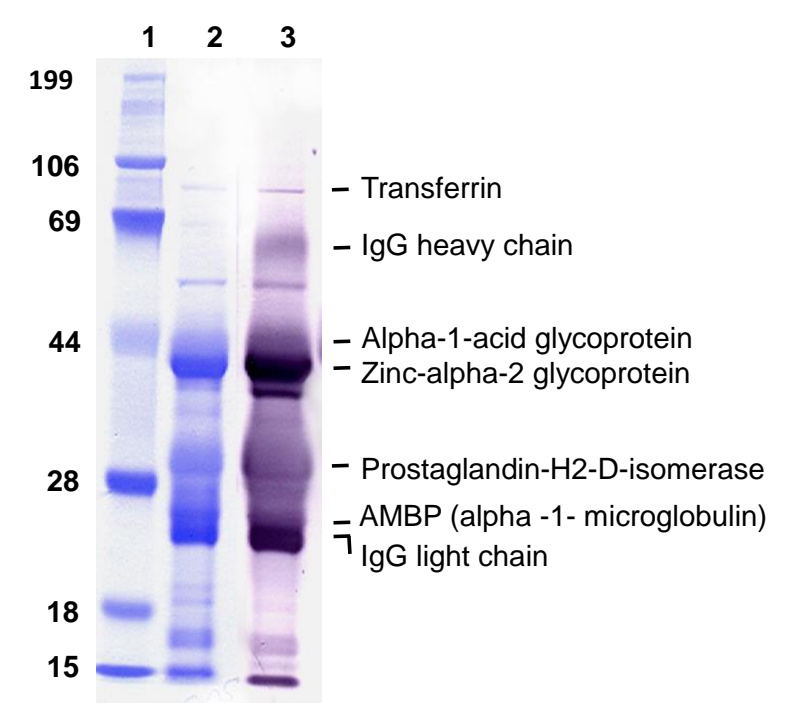

Fig. (5). Characterization of the reactivity of the polyclonal antiurinary protein antibody with purified urinary proteins by Western blot analysis. Aliquots of the purified urinary protein preparation, treated by affinity chromatography to remove only albumin, and molecular weight standards were subjected to non-denaturing polyacrylamide gel electrophoresis using a $12 \%$ acrylamide gel and electroblotted onto a polyvinylidene difluoride membrane. Lane 1, Coomassie Blue stained gel of electrophoretically-resolved molecular weight standards with molecular weights indicated in units of kilodaltons. Lane 2, Coomassie Blue stained gel containing electrophoretically-resolved, albumin-depleted, urinary protein preparation. Lane 3, Western blot of electrophoretically-resolved, albumindepleted, urinary proteins indicating the bands bound by the polyclonal anti-urinary protein antibody. The identity of the major protein components of the purified urinary protein preparation bound by the anti-urinary protein polyclonal antibody are indicated based on the binding of monoclonal antibodies specific for each of these proteins in separate Western blot experiments (data not presented).

minuric samples had an AUC of $0.8782(95 \% \mathrm{CI}=0.0 .8286$ to 0.9278 , Fig. 7).

\section{DISCUSSION}

Protein, present in the urine, is the combined result of the physiological processes of glomerular filtration and tubular reabsorption. Normoproteinuric individuals with normal kidney function excrete large amounts of small molecular weight peptides and amino acids in their urine. These molecules, based on their size and charge, are freely filtered at the glomerulus and are not reabsorbed by the renal tubules. As diabetic kidney disease progresses, the size profile of excreted proteins changes from predominantly small molecular weight species to predominantly large proteins of greater than approximately $60 \mathrm{kDa}$ [26-28], due to enhanced glomerular permeability and/or impaired tubular absorption [2831]. Proteinuria can be classified based on the molecular weight of the predominant proteins present in the urine. Glomerular proteinuria is characterized by the presence of predominantly large molecular weight proteins, such as immunoglobulin $(150 \mathrm{kDa})$, Trf $(80 \mathrm{kDa})$, albumin $(60 \mathrm{kDa})$, alpha 1 anti-trypsin $(52 \mathrm{kDa})$, and alpha 1 acid glycoprotein

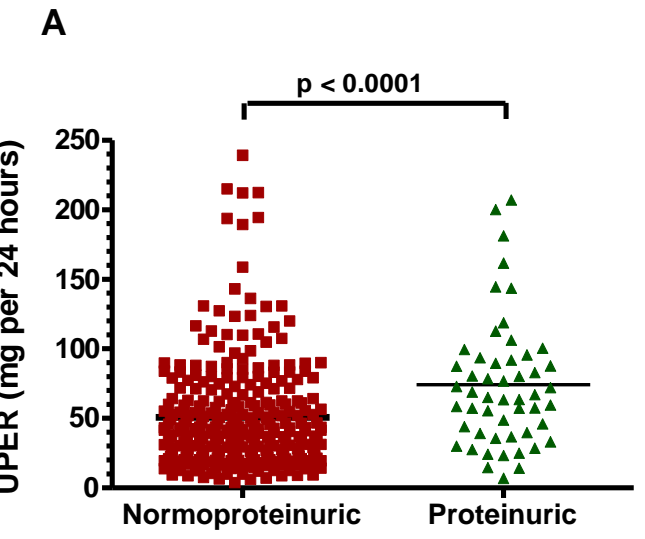

\section{B}

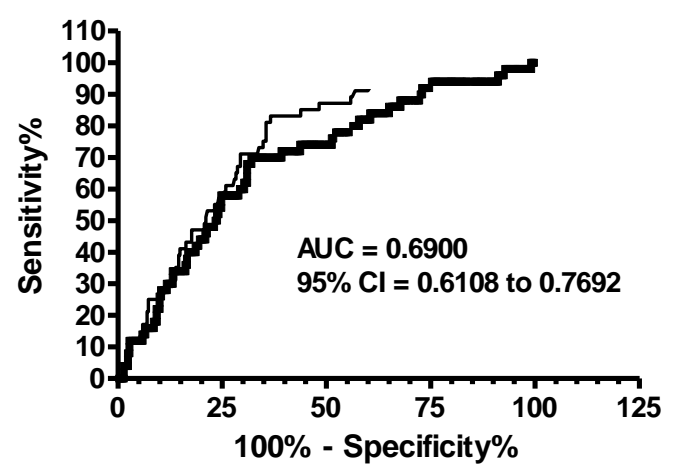

Fig. (6). Comparison of 24-hour urinary protein excretion rate (UPER), measured by the polyclonal antibody-based immunoassay, to 24-hour total protein excretion rate, measured by a clinical laboratory reference method, in identifying proteinuria. Normoproteinuric $(n=291)$ and proteinuric $(n=52)$ urine samples, classified by the total protein reference method, were analyzed by urinary protein immunoassay and the UPER for each sample was determined. Panel A, an unpaired, two-tailed, t-test $(\alpha=0.05)$ was used to assess the statistical significance of the difference in means $(\mathrm{m})$ of the normoproteinuric $(\mathrm{m} \pm$ standard error of the mean $[\mathrm{SEM}]=50.8 \pm$ $2.3 \mathrm{mg}$ per 24 hours $)$ and proteinuric $(\mathrm{m} \pm \mathrm{SEM}=74.3 \pm 6.4 \mathrm{mg}$ per 24 hours) groups. Panel B, a receiver-operating characteristics curve of the immunoassay results. AUC, area under the curve; CI, confidence interval.

$(43 \mathrm{kDa})$. Tubular proteinuria is characterized by the presence of predominantly low molecular weight proteins, such as alpha 1 microglobulin $(26 \mathrm{kDa})$, immunoglobulin light chains $(25 \mathrm{kDa})$, retinol binding protein $(20 \mathrm{kDa})$, and beta 2 microglobulin $(12 \mathrm{kDa})$. In mixed proteinuria, both high and low molecular weight proteins are predominant, while in overflow proteinuria, monoclonal free immunoglobulin light chains, such as Bence-Jones proteins, are commonly observed [28].

The urinary proteins that we have purified from human urine are a heterogenous collection of acute phase reactants, enzymes, and structural proteins derived from the serum or the tubular epithelium [32]. Based on protein molecular 
weight, both the LC/MS-MS analysis of the purified urinary proteins and the identified specificities of the anti-urinary protein polyclonal antibody are suggestive of a mixed proteinuric profile. Zinc-alpha-2 glycoprotein, alpha-1 acid glycoprotein, alpha-1 microglobulin, and IgG, specificities identified in our polyclonal antibody, have been identified as specific biomarkers for diabetic nephropathy [33]. In a proteomic analysis of urines from type II diabetic patients, the concentration of zinc-alpha- 2 glycoprotein increased across normoalbuminuric, microalbuminuric, and macroalbuminuric clinical groups, suggesting clinical utility as a biomarker of disease progression [34]. Using two-dimensional PAGE, multiple charged species of urinary albumin, Trf, zinc-alpha2 glycoprotein, alpha-1 antitrypsin, haptoglobulin, alpha-1 microglobulin, and alpha-1 acid glycoprotein were identified due to differential glycosylation $[35,36]$. The size selection and charge permeability barriers of glomerular filtration may be the reason why the presence of biochemically-modified forms of these proteins in urine is reflective of glomerular disease [35].

Analytically and clinically, the urinary protein immunoassay performed well. The analytical performance results were acceptable for a non-automated, competitive immunoassay. Clinically, the measurement of a 24 hour urinary protein excretion rate using the urinary protein immunoassay was statistically equivalent to the measurement of either a 24 hour total protein excretion rate or a 24 hour albumin excretion rate in distinguishing between normal and pathological samples. Notably, a ROC curve analysis of this data set demonstrated that the urinary protein immunoassay was better able to distinguish between normoalbuminic and albuminuric samples than between normoproteinuric and proteinuric samples. We hypothesize that this difference may be due to the large amount of small molecular weight proteins, peptides, and amino acids detected in the total protein assay that are not detected in the albumin or urinary protein assays.

Our novel assay development approach has several advantages. First, we performed a rigorous purification and characterization of urinary proteins from normoproteinuric and proteinuric diabetics and generated polyclonal antibodies specific for this collection of proteins. The purification strategy focused on non-albumin urinary proteins in a size range that should detect glomerular and/or tubular dysfunction. Additionally, the use of a polyclonal antibody in the new immunoassay permits the detection of multiple epitopes on multiple proteins in a sample based on their concentration and immunogenicity. The validity of this approach was confirmed by: 1) the identification of specific urinary proteins and anti-urinary protein polyclonal antibody reactivities that have been reported by other groups to have diagnostic significance in diabetic nephropathy, and 2) the clinical utility of the polyclonal antibody-based immunoassay in differentiating between the different clinical categories of albuminuria. Multiple epitope detection on several proteins may afford a better measure of urinary proteinuria than the detection of epitopes on a single protein, such as albumin. Additional studies are needed to prove this hypothesis.

Despite these advantages, our studies had several limitations. The generation of polyclonal antibodies directed against a heterogeneous collection of proteins provides a
A

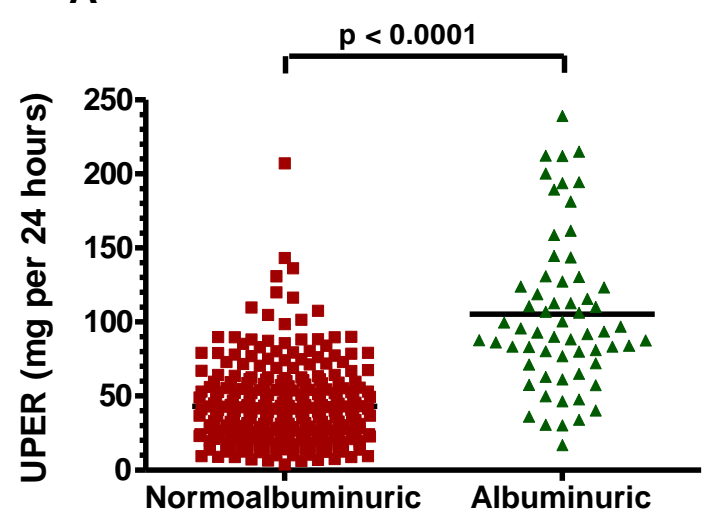

B

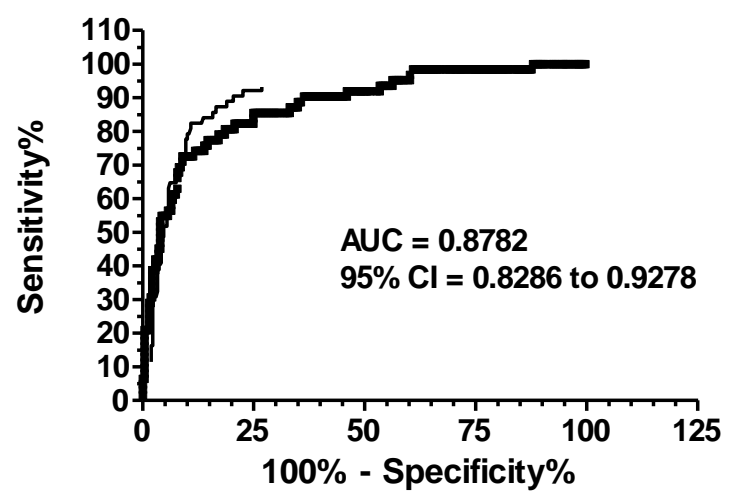

Fig. (7). Comparison of 24-hour urinary protein excretion rate (UPER), measured by the polyclonal antibody-based immunoassay, to 24-hour albumin excretion rate, measured by a clinical laboratory reference method, in identifying albuminuria. Normoalbuminuric $(n=281)$ and albuminuric $(n=62)$ urine samples, classified by the albumin reference method, were analyzed by urinary protein immunoassay and the UPER for each sample was determined. Panel A, an unpaired, two-tailed, t-test $(\alpha=0.05)$ was used to assess the statistical significance of the difference in means $(m)$ of the normoalbuminuric $(\mathrm{m} \pm$ standard error of the mean $[\mathrm{SEM}]=43.1 \pm$ $1.6 \mathrm{mg}$ per 24 hours $)$ and albuminuric $(\mathrm{m} \pm \mathrm{SEM}=105.2 \pm 6.6 \mathrm{mg}$ per 24 hours) groups. Panel B, a receiver-operating characteristics curve of the immunoassay results. AUC, area under the curve; CI, confidence interval.

limited supply of a unique immunological reagent and raises important questions regarding antigenic crossreactivity in the assay and which proteins and protein epitopes are most diagnostically important. In these studies, we were able to identify the predominant proteins present in the urinary protein preparation and the major immunogenic specificities recognized by the polyclonal antibody. However, the urinary protein preparation contains proteins, and the polyclonal antibodies contain reactivities, that we have not characterized. The studies described here were not designed to identify which urinary proteins or protein epitopes, detected by our immunoassay, are most diagnostically informative. Nor did our studies address potential immunological crossreactivity between urinary protein epitopes that may be present in the 
anti-urinary protein polyclonal antibodies and the effect of that crossreactivity on sample analysis results. Additional studies currently ongoing in our laboratory involve the development of individual monoclonal antibody-based immunoassays and a multiplexed panel of monoclonal antibodybased immunoassays specific for the predominant urinary proteins present in the urinary protein preparation that are detected by the anti-urinary protein polyclonal antibody. These assays will allow a more thorough investigation of antigenic reactivity and will permit the identification of the most diagnostically informative, non-albumin, urinary proteins and protein epitopes.

Another limitation of our studies was that the specificity of the polyclonal antibodies, and the immunoassay, could be "biased" by the small number of patients used to generate the sample pool from which the urinary proteins were purified and may not be reflective of the urinary proteins in the diabetic population at-large. We were not able to examine the urinary protein profile or reactivity in the immunoassay of the individual patient samples that constituted the pool from which the urinary protein preparation was purified, as these samples were provided to us as a pool. Also, the diagnostic utility of the polyclonal antibody used in the assay may be limited by the inter-patient variation of proteins expressed in urine and the differing affinity of the polyclonal antibody for these differentially expressed proteins. Both of these scenarios are unlikely, as the diagnostic utility of the predominant urinary proteins identified in our purified preparation and the immunoreactive specificities detected in the anti-urinary protein polyclonal antibody demonstrated by our results have been validated in published studies from other laboratories. Our current studies involving individual monoclonal antibody-based immunoassays will allow a more thorough investigation of intra- and inter-patient variation in protein excretion.

It is interesting to speculate whether this collection of non-albumin urinary proteins, or specific non-albumin proteins within the $20 \mathrm{kDa}$ to $90 \mathrm{kDa}$ range, would provide an earlier indication of glomerular and/or tubular dysfunction than an albumin measurement. As urinary proteinuria is the result glomerular filtration and tubular reabsorption based on the size and charge of the filtered protein, it is conceivable that a protein or proteins within this molecular weight range may be a better indicator than albumin of the breakdown of these physiological processes. Additional studies with single timepoint and longitudinally-collected samples from normal and diabetic individuals, using the urinary protein immunoassay and monoclonal antibody-based ELISA methods specific for individual proteins within this molecular weight range, will be needed to answer this important question.

\section{CONCLUSION}

The measurement of 24 hour urinary protein excretion rates using the urinary protein immunoassay is clinically equivalent to the Microprotein (M-TP) method to the quantitation total protein and the Microalbumin (MA) method for the quantitation of albumin in identifying proteinuria or albuminuria.

\section{ACKNOWLEDGEMENTS}

Funding for the studies described in this manuscript was obtained from University Equity Capital, New Haven, CT (now PharmLogic, LLC; Warwick, RI 02886, USA).

The authors wish to thank Dr. Michael Steffes for his critical review of this manuscript.

\section{CONFLICT OF INTEREST DISCLOSURE}

The authors declare that there are no conflicts of interest regarding the publication of this manuscript. Funding of the research played no role in the study design; collection, analysis, and interpretation of data; preparation of this manuscript; or in the decision to submit the report for publication.

BH and DLV are paid consultants of PharmLogic LLC; Warwick, RI 02886; USA.

\begin{tabular}{|c|c|c|}
\hline \multicolumn{3}{|c|}{ ABBREVIATIONS } \\
\hline$\% \mathrm{CV}$ & $=$ & percent coefficient of variation \\
\hline AUC & $=$ & area under the curve \\
\hline CFA & $=$ & Complete Freund's Adjuvant \\
\hline $\mathrm{CI}$ & $=$ & confidence interval \\
\hline ESRD & $=$ & end-stage renal disease \\
\hline HPLC & $=$ & $\begin{array}{l}\text { high performance liquid chromatogra- } \\
\text { phy }\end{array}$ \\
\hline IFA & $=$ & Incomplete Freund's Adjuvant \\
\hline $\mathrm{kDa}$ & $=$ & kilodaltons \\
\hline LC-MS/MS & $=$ & $\begin{array}{l}\text { liquid chromatography tandem mass } \\
\text { spectrometry }\end{array}$ \\
\hline LLQ & $=$ & lower limit of quantitation \\
\hline Lys-C & $=$ & endoproteinase Lys-C \\
\hline M & $=$ & mean \\
\hline $\mathrm{ROC}$ & $=$ & receiver-operating characteristic \\
\hline PAGE & $=$ & polyacrylamide gel electrophoresis \\
\hline PVDF & $=$ & polyvinylidene fluoride \\
\hline RT & $=$ & room temperature \\
\hline SEM & $=$ & standard error of the mean \\
\hline SDS-PAGE & $=$ & $\begin{array}{l}\text { sodium dodecyl sulfate- } \\
\text { polyacrylamide gel electrophoresis }\end{array}$ \\
\hline TMB & $=$ & $3,3^{\prime}, 5,5^{\prime}$ tetramethyl benzidine \\
\hline $\operatorname{Trf}$ & $=$ & transferrin \\
\hline ULQ & $=$ & upper limit of quantitation \\
\hline UP & $=$ & urinary protein \\
\hline UPER & $=$ & urinary protein excretion rate \\
\hline
\end{tabular}

\section{REFERENCES}

[1] Atkins, R.C.; Zimmet, P. Diabetic kidney disease: act now or pay later. Kidney Int, 2010, 77, 375-377. 
[2] Reutens, A.T.; Prentis, L.; Atkins, R. In The Epidemology of Diabetes Mellitus, $2^{\text {nd }}$ ed.; Ekoe J-M., Rewers M., Williams R., Zimmet P., Eds.; John Wiley \& Sons: Chichester, 2008, pp. 499-518.

[3] National Institutes of Health, National Institute of Diabetes and Digestive and Kidney Diseases: U.S. Renal Data System, USRDS 2012 Annual Data Report: Atlas of Chronic Kidney Disease and End-Stage Renal Disease in the United States. http://www.usrds.org. (accessed 5 February 2013).

[4] Sicree, R.; Shaw, J.; Zimmet, P. In Diabetes Atlas, $3^{\text {rd }}$ ed.; D. Gan, Ed.; International Diabetes Federation: Brussels, 2006, pp. 15-109.

[5] Barratt, J.; Topham, P. Urine proteomics: the present and future of measuring urinary protein components in disease. Can. Med. Assoc. J., 2007, 177, 361-368.

[6] Mogensen, C.E.; Christensen, C.K. Predicting diabetic nephropathy in insulin-dependent patients. N. Engl. J. Med. 1984, 311, 89-93.

[7] Ruggenenti, P.; Fossi, A.; Llieva, A.P.; Bruno, S.; Llieva, L.P.; Brusegan, V.; Rubis, N.; Gherardi, G.; Arnoldi, F.; Ganeva, M.; Ene-lordache, B.; Gaspari, F.; Perna, A.; Bossi, A.; Trevisan, R.; Dodesini, A.; Remuzzi, G. for the Bergamo Nephrologic Diabetes Complications (BENEDICT) Investigators. Preventing microalbuminuria in type II diabetes. N. Engl. J. Med., 2004, 351, 1941-1951.

[8] Parving, H-H.; Lehnert, H.; Brochner-Mortensen, J.; Gomis, R.; Andersen, S.; Arner, P. for the Irbesartan in Patients with Type 2 Diabetes and Microalbuminuria Study Group. The effects of irbesartan on the development of diabetic nephropathy in patients with type II diabetes. N. Engl. J. Med., 2001, 345, 870-878.

[9] Lewis, E.J.; Hunsicker, L.G.; Clarke, W.R.; Beri, T.; Pohl, M.A.; Lewis. J.B.; Ritz, E.; Atkins, R.C.; Rohde, R.; Raz, I. Renoprotective effects of angiotensin receptor antagonist irbesartan in patients with nephropathy due to type II diabetes. N. Engl. J. Med., 2001, 345, 851-860.

[10] Orsonneau, J.L.; Douet, P.; Massoubre, C.; Lustenberger, P.; Bernard, S. An improved pyrogallol red molybdate method for determining total urinary protein. Clin. Chem., 1989, 35, 2233-2236.

[11] Marshall, T.; Williams, K.M. Comparison of commassie brilliant blue protein dye binding assays for determination of urinary protein concentration. Clin. Chem., 1987, 33, 577-578.

[12] Iwata, J.; Nishikaze, O. New micro-turbidimetric method for determination of protein in cerebrospinal fluid and urine. Clin. Chem., 1979, 25, 1317-1319.

[13] Pesce, M.A.; Strande, C.S. A new micromethod for the determination of protein in cerebrospinal fluid and urine. Clin. Chem., 1973, 19, 1265-1267.

[14] Rice EW. Improved biuret procedure for routine determination of urinary total proteins in clinical proteinuria. Clin. Chem., 1975, 21, 398-401.

[15] Giampietro, O.; Penno, G.; Clerico, A.; Cruschelli, L.; Luchetti, A.; Nannipieri, M.; Cecere, M.; Rizzo, L.; Navalesi, R. Which method for quantitating "microalbuminuria" in diabetes? Comparison of several immunological methods (immunoturbidometric assay, immunonephalometric assay, radioimmunoassay, and two semi quantitative tests) for the measurement of albumin in urine. Acta Diabetol., 1992, 28, 239-245.

[16] Roberts, W.L.; Calcote, C.B.; Cook, C.B.; Gordon, D.L.; Moore, M.L.; Moore, S.; Scheer, W.D.; Snazelle, B.A. Comparison of four commercial urinary albumin (microalbumin) methods: implications for detecting diabetic nephropathy using random urine samples. Clin. Chem. Acta, 1998, 273, 21-33.

[17] McElderry, L.A.; Tarbit, I.F.; Cassells-Smith, A.J. Six methods for urinary proteins compared. Clin. Chem., 1982, 28, 356-360.

[18] Lamb, E.J.; MacKenzie, F.;Stevens, P.E. How should proteinuria be detected and measured? Ann. Clin. Biochem., 2009, 46, 205-217.

[19] Marshall, T.; Williams, K.M. Total protein determinations in urine: elimination of a differential response between the coomassie blue and pyrogallol red protein dye binding assays. Clin. Chem., 2000, 46, 392-398.

[20] Martin, H. Laboratory measurement of urine albumin and urine total protein in screening for proteinuria in chronic kidney disease. Clin. Biochem. Rev., 2011, 32, 97-102.

[21] Miller, W.G.; Bruns, D.E.; Hortin, G.L.; Sandberg, S.; Aakre, K.M.; McQueen, M.J.; Itoh, Y.; Lieske, J.C. Seccombe, D.W.; Jones, G.; Bunk, D.M.; Curham, G.C.; Narva, A.S.; on behalf of the National Kidney Disease Education Program-IFCC Working Group on Standardization of Albumin in Urine. Clin. Chem., 2009, 55, 24-38.

[22] Fairbanks, G.; Steck, T.L.; Wallach, D.F. Electrophoretic analysis of the major polypeptides of the human erythrocyte membrane. Biochem., 1971, 10, 2606-2617.

[23] Ornstein, L. Disc electrophoresis, background and theory. Ann. N.Y. Acad. Sci. 1964, 121, 321-349.

[24] Williams, K.R.; Stone, K.L. In gel digest of SDS-PAGE separated proteins: observations from internal sequencing of twenty-five proteins. In Techniques In Protein Chemistry, Vol. 1; J.W. Crabb, Ed.; Academic Press: San Diego, 1995, pp. 143-152.

[25] Wu, S.L.; Kim, J.; Hancock, W.S.; Kayer, B. Extended range proteomic analysis (ERPA): a new and sensitive LC-MS platform for high sequence coverage of complex proteins with extensive posttranslational modifications-comprehensive analysis of beta casein and epidermal growth factor receptor (EGFR). J. Proteome Res., 2005, 4, 1155-1170.

[26] De Jong, P.E.; Bakker, S.J.; Gansevoort, R.T. What to measure albuminuria or total proteinuria. Am. J. Kidney Dis., 2011, 57, 1-2.

[27] Baboush, O.; Grubb, A.; Rippe, B.; Tencer, J. Urine excretion of protein $\mathrm{HC}$ in proteinuric glomerular disease correlates to urine IgG but not albuminuria. Kidney Int., 2001, 60, 1904-1909.

[28] Smith, E.R.; Cai, M.M.X.; McMahon, L.P.; Wright, D.A.; Holt, S.G. The value of simultaneous measurements of urinary albumin and total protein in proteinuric patients. Nephrol. Dial. Transplant. 2012, 27, 1534-1541.

[29] Kashif, W.; Siddiqi, W.; Dincer, A.D.; Dincer, H.E.; Hirsh, S. Proteinuria: how to evaluate an important finding. Clev. Clin. J. Med., 2003, 30, 535-547.

[30] Kanyar, Y.S.; Liu, Z.Z.; Kashihara, N.; Wallner, E.L. Current status of the structural and functional basis of glomerular filtration and proteinuria. Semin. Nephrol., 1991, 11, 390-413.

[31] Gauch, A.; Deen, W.M.; Myers, B.D. Charge selectivity of the glomerular filtration barrier in healthy and nephritic humans. $J$. Clin. Invest., 1993, 92, 2272-2282.

[32] Price, C.P.; Newman, D.J.; Blirup-Jensen, S.; Guder, W.G.; Grubb, A.; Itoh, Y.; Johnson, M.; Lammers, M.; Packer, S.; Seymour, D.; and the IFCC Working Group on Urine Proteins. First international reference preparation for individual proteins in urine. Clin. Biochem., 1998, 31, 467-474.

[33] Jain, S.; Rajput, A.; Kumar, Y.; Uppuluri, N.; Arvind, A.S.; Tatu, $\mathrm{U}$. Proteomic analysis of urinary protein markers for accurate prediction of diabetic kidney disorder. J. Assoc. Phys India, 2005, 53, 513-520.

[34] Rao, P.V.; Lu, X.; Standley, M.; Patlec, P.; Neclima, G.; Girisesh, G.; Dakshinamurthy, K.V.; Roberts, C.T.; Nagalla, S.R. Proteomic identification of urinary biomarkers of diabetic nephropathy. Diab. Care, 2007, 30, 629-637.

[35] Varghese, S.A.; Powell, T.B.; Budisavljevic, M.N.; Oates, J.C.; Raymond, J.R.; Almeida, J.S.; Arthur, J. M. Urine biomarkers predict the cause of glomerular disease. J. Am. Soc. Nephrol., 2007, 18, 913-922.

[36] Wilson, N.L.; Schulz, B.L.; Karlsson, N.G.; Packer, N.H. Sequential analysis of N- and O-linked glycosylation of 2D-PAGE separated glycoproteins. J. Proteome Res., 2002, 1, 521-529. 